\title{
MUSEUM MANAGEMENT AND PRIVATE MUSEUMS IN EGYPT
}

Ahmed Motawea Hussein SHAIKHON *

Egyptian Ministry of Tourism and Antiquities, Egypt

\begin{abstract}
In Egypt, the museums are run by the government while Lack of Financial resources for running costs and purchasing budgets threatens to derail the objectives of even the museum and mission of these institutions, so many countries have moved to Involve the private sector in the field of museums, While many private museums run by people have been established, as well as specialized museums run by government agencies, such as the Nile Museum in Aswan, run by the Ministry of Water Resources and Irrigation, and the Agricultural Museum run by the Ministry of Agriculture. This paper aims to shed light on museums run by the Ministry of Antiquities and other museums run by government agencies as well as private museums in Egypt.

Keywords

Privatization, Cultural Heritage, Museums, Private Museum, Independent.
\end{abstract}

\section{Introduction}

A museum is internationally defined as, "A non-profit making permanent institution in the service of society and of its development, open to the public, which acquires, conserves, researches, communicates and exhibits, for purposes of study, education, and enjoyment, the tangible and intangible evidence of people and their environment" (ICOM, 2006). Lack of Financial resources for running costs and purchasing budgets threatens to derail the objectives of even the museum and mission of these institutions. So many countries have moved to the privatization of museums this subject of heated public debate. It highlights crucial social and cultural problems relating to global privatization that the world community will have to face in the coming years.

In some countries the task of the decision-maker is changed to for the director and advisors of the museum instead of the minister, however, the minister still the one who gives the framework of the cultural activities general, this change after privatizing the museums allowed the museum to keep the extra income and use it to develop and fund the activities and any expansion for the museum. This paper examines the idea of privatization of public museums and independent museum and reviews the privatization of museums in the Netherlands and the satiation of Egyptian museums Relation of new private museums to heritage rather than to traditional museums was reinforced by many specialists who stressed and exaggerated the features that differentiated them from the established sector.

*Corresponding author: ahmed_motawea83@yahoo.com 


\section{Privatization and the museums:}

The idea itself was a transformation from state institutions to more democratic private institutions concerning the mission of the museum education, cultural activities, etc... Without following special political agendas and giving freedom for cultural life. Nowadays the museum is important as an institution serving a diverse and increasing array of roles in cultural life. The development from the traditional repository of a country's material culture to the multi-service institution is well-documented (Hooper-Greenhill, 1992; McLean, 1997; Schubert, 2000). Consequently, visitors have increased, and the increasing interests of diverse publics and other stakeholders have created new demands to which museums must respond. However funds to meet these needs have not kept pace with the rising demands for service; thus as demands have increased, problems have emerged.

There has been considerable discussion in the museum world concerning the 'privatization' of public museums. Many connect the term simply with selling public institutions to private firms, and with governments passing on their responsibilities for the arts and culture to the market. In this context, the term 'privatization of public museums' means the transfer of authority over collections, buildings, operations, and/or responsibility for funding one entity to another (Urice, 1995:2). The present is marked by a deep uncertainty about how museums and their role in society should be interpreted, and lack of money for running costs and purchasing budgets threatens to derail the objectives of even the most established institutions. With this rapidly changing context, how does the trend towards a public/private contribution

\section{The idea of privatization:}

The vast majority of the supporter of the idea of privatization from the non-specialist of the cultural heritage and museums think that everything in the hand of the government is corrupted and not have a good operating system and why the art and heritage will be the exception if everything is down and corrupted. they think that the operation of the art and cultural life should be in the hand of the private sector which can be more careful and operate it according to the way the public wants to see and serve them this can keep the safety of the art more and possession of the art in their opinions should follow supply and demand and this what can be offered in the private hands. (veniris, 2013).

Using the privatization to change the government organization to a private foundation was one of the main features which affect the museum's system in many countries Where the task of the decision-maker is changed to for the director and advisors of the museum instead of the minister, however the minister still the one who gives the framework of the cultural activities in general .in terms of funding one of the results of privatization that changing in the mentality 
system of the foundation. Before the privatization, the museums get subsidies from the government as public fund and they weren't interested in extra income through developing the museum activities, because they know that any extra fund will return to the treasury .this change after privatizing the museums allowed the museum to keep the extra income and use it to develop and fund the activities and any expansion for the museum.

The wider international perspective has been in many countries a similar process of cuts indirect public funding, pushing museums 'into the marketplace', with a consequent need to emphasize income generation and marketing as never before (Moore, 1997:1). With increased resistance to taxation, increasing attention is being given to 'user charges' as a way that government can raise revenues without violating pledges not to increase taxes (Anderson, 1991). Therefore, pricing can influence museums to think more clearly about the benefits they offer the public and what the public perceives as the value of a visit. Another question is what are the factors that might influence a visitor's perceptions of the value-for-money offered by a recent visit to the museum?

Through the privatization of cultural heritage and museums, we should be aware of the negative examples which it shouldn't be implemented when we are dealing with the heritage. And the main aim of evolving the private sector in the field of heritage is to enhance and improve the service of the cultural heritage, and raise the economy.

\section{Independent museums:}

In fact, the idea of independent museums can be a good point according to Raphael Samuel and his proof of how this can democratize history from the controlling of the authority to follow agenda (Samuel, 1999).

Raphael Samuel in his book theatres of memory ascent the raising of the independent museums as a motivating engine of the growing idea of democratization of history and art. He claimed that history and heritage study is dominated by the professional and experts and it just limited between a small group of people and who interested in, and considered as paper in the hand of the students and relatively narrow. (Samuel, 1999). Samuel thinks that to keep the heritage study and the history literary between a small number of the experts or professional make it narrow and limited and such those kinds of the small independent museums supporting the idea of history for you, and making the normal people search for their own history and became interested in it. With evaluating of increasing the small private museums Samuel said that the multiplication of curators and mini-museums was one of the most remarkable additions to the ranks of Britain's memory keepers or notable augmentation of them. It worthy to mention that in England to support the investment of small businesses the government allows investing by 
making fewer rules and restrictions and one of those small projects in the areas of the high unemployment rate is building the independent museum, and cultural heritage industry. This example of heritage use. the cultural heritage and the museum industry can have a good impact on the community through presenting the example of iron bridge Gorge museum used the main fund of the museum to train young trainee to establish jack field tile workshop and center for the renovation of the old one tiles and produce new one from the old models in 1980 funds for the manpower increased with high percentage. (West, 1988, pp. 19-32)

In this way, the theory of heritage was understood to be the impact of the deindustrialization of enterprise culture and it can be a solution to the exploitation of young employment people. The idea now is how we can improve the role of the museum to extend being a place of preserving of Antiques to provide education and factory of the revival of old industry and how can help in the economy field to create jobs, enhancing the role of the culture in the economic cycle.

No doubt that the public museum's proper museums were the exponents of intangible heritage, immaterial values, historical knowledge, and cultural meaning, but without omitting the role of the mini private museum which established to reflect the social life and represented the notions of the living community which is closer to this kind of heritage than the public museums.

\section{Museum privatization in Netherland:}

The museums in Netherland became under the responsibility of the board of trustees and the role of the general manager of the museum changed to be appointed by the ministry of tourism and he is the connection between the public sector represented in the government ministry of culture and the private sector represented in the board of the museum .and the museum itself is run as private sector foundation.

The role of the board is to hire the director and fire him -appoint financial auditors- approves the annual budget and financial report -give advice and supervise the board itself does not appoint anyone from the civil servants in the ministry of culture to avoid conflicting in interest. The staff of the museum following the worker's council of the museum. The social reason for this change that the management of the national museums became utterly dead blocked, all authorities in the hand of the ministry of culture not with museum directors his own responsibility to keep the quality of scholarly and professional work. The bureaucracy of making decisions and the minister was the only one who carries any problem could happen.

The third reason for the privatization of the museum coming from the down leadership of the government and public sector leaders to think about an alternative way to run the organizations 
.and the idea of privatization wasn't just an intangible idea but moreover good solution serve the shortcomings.

in 1904 first group of six national museums has been privatized among them Vangogh museum Amsterdam, and Boerhaave museum for the history of science Leiden those museums were at the beginning of declaring the ministry of culture to change the museums from state-owned institution to private sector organization. The two museums were ready for such a change they were suite organizationally structure and their condition was good for this kind of change (Engleman, 1996).

The rest of the museum needs a long strategy plan to receive this kind of change in the administration system and long operation to adequate with the idea of the privatization. Ministry of culture in the Netherland started to go-ahead to release the necessary budget for the renovation and restoration of the museums like the museum of ethnology in Leiden. In 1995 turning point in the museum strategy in Netherland, the last group of three museums was privatized Rijks museum in Amsterdam, Natural History Museum, and National Museum of Antiques Leiden (Englesman, 1996).

Steven Englsman tried to analyze the success of the idea of privatization of the museum in the Netherlands that the supporter and the opponents became agree with the same concept that the privatization improved the role of the museum, and didn't affect the budget of the museum and instead of the idea of cut the public funding from the museum as the opponents considered it is trick from the government with contradiction it increased by making the hidden coasts visible (what called increasing the operational budget)for example the national building Agency it is responsible for the public building which in use and they spend on it, was receiving annual budget to provide for housing need for all civil services, on the other hand now the institutions museum have own funding for housing revenue which coming from rental income (Englsman,1996).

The Netherland experience in the privatization of the museum encouraged many countries to follow the same strategy like Germany, and Japan with changes in the model of outsourcing management for the private sector, and Japan considered it as a solution for the problem of funding the museum, and budget-cutting from the culture.

\section{Independent Museum in Egypt:}

Egypt has a great wealth of historical monuments, whether Pharaonic, Islamic, Roman or other monuments. In Egypt, there are a large number of Pharaonic museums and art museums that contain rare and priceless collections. The Egyptian museums vary among historical, artistic, heritage, and cultural museums and open-air museums, These museums are managed by the 
governmental sector, run by the owners, and most museums in Egypt are affiliated with the Ministry of Antiquities, especially the Antiquities Museums, where the ministry has a museum department that sets the supreme strategy and is committed to museums throughout the republic. During the past two decades, Egypt has begun building two grand museums with a new vision was developed for their management through a board of trustees for each museum to make the museum an independent body.
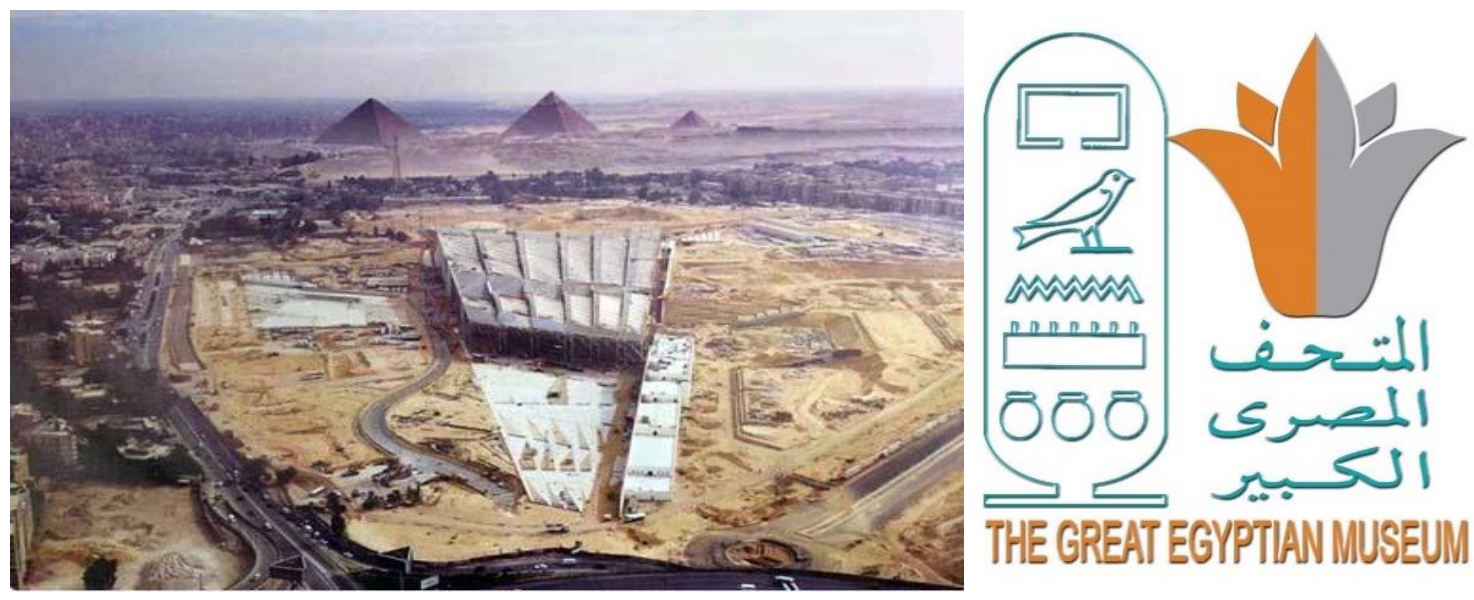

Fig (1) Grand Egyptian Museum (Ministry of Antiquities).

\section{Grand Egyptian Museum:}

The Grand Egyptian Museum is located a few miles west of Cairo near the pyramids of Giza. It is built on an area of 117 acres for 550 million dollars and is being built to be the world's largest museum of monuments, accommodating 5 million visitors annually. The museum will house more than 100,000 artifacts from the Pharaonic, Greek, and Roman eras, as well as commercial and entertainment services, a restoration center, and a museum garden that will plant the trees that were known to ancient Egyptians (fig1).

\section{National Museum of Egyptian Civilization:}

The museum is located in the city of Fustat in Cairo on an area of 33.5 acres. The Museum accommodates fifty thousand archaeological pieces that tell the stages of the development of Egyptian civilization in addition to a presentation of the achievements of Egyptian people in the various fields of life from the dawn of history to the present time. It also contains models, photographs, manuscripts, oil paintings, artifacts, and monuments from the Stone Age, Pharaonic, Roman, Coptic, And the modern era(fig2). 

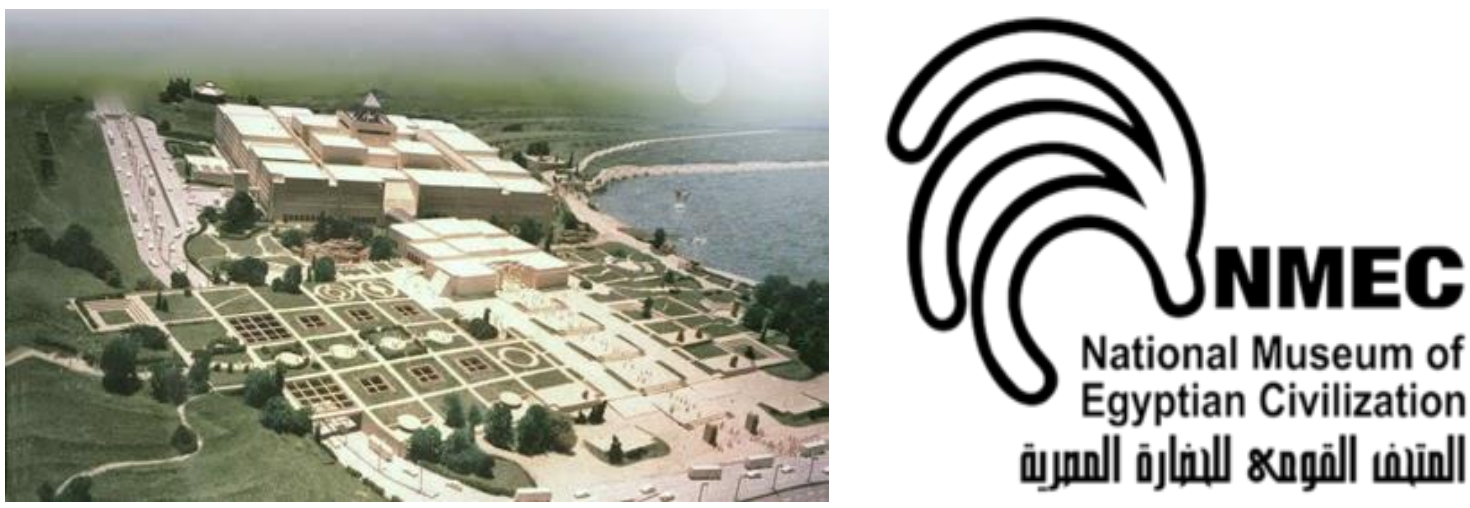

Fig (2) National Museum of Egyptian Civilization (Ministry of Antiquities).

\section{The way to museum management:}

The vision of the Egyptian government to separate the ownership of the Grand Egyptian Museum from its administration, by assigning the management of the museum with various fields and investment activities, to an international company specialized in the management of museums, taking into account the project of great importance, The board of trustees of the National Museum of Civilization and the Board of Trustees of the Egyptian Grand Museum has been formed. Its members include several Egyptian and foreign personalities who are experienced in various fields of archeology, science, politics, finance and planning to be able to manage the museum as one of the largest and most important Egyptian museums. The museum is an independent economic body. The council supervises all the activities undertaken by the museums and sets up their work programs, as well as managing the funds of the museums by studying the grants, donations, gifts, and gifts presented to them both inside and outside the country. The Board of Trustees shall appoint a director for each museum and its two deputies, and shall represent the director of the museum in all matters relating to him and before the judiciary.

The antiquities museums can't even adequately look after the pieces they already have, let alone keep up with new finds, but also have limited resources. The ministry's have hundreds of thousands of [artifacts] in storerooms, both in the museums and at archaeological sites. It's about time these pieces see the light with the establishment of new museums in partnership with the private sector. In practice, the key to the private management of museums containing national treasures would be a profit-sharing agreement between the state and the private investor.

In 2020, the Ministry of Antiquities established an archaeological museum containing a large number of real artifacts, in partnership with the private sector in Egypt for the first time, so that the ratio of partnership is equal between the ministry and the private partner. The cost of the 
construction of the Hurghada Antiquities Museum is more than 160 million pounds, which will be borne entirely by the private partner, and the Ministry of Antiquities will share various artifacts from various Egyptian antiquities.

The museum is currently under full management by the Ministry of Tourism and Antiquities, the Tourism and Antiquities Police, while the company manages the museum's services and marketing.

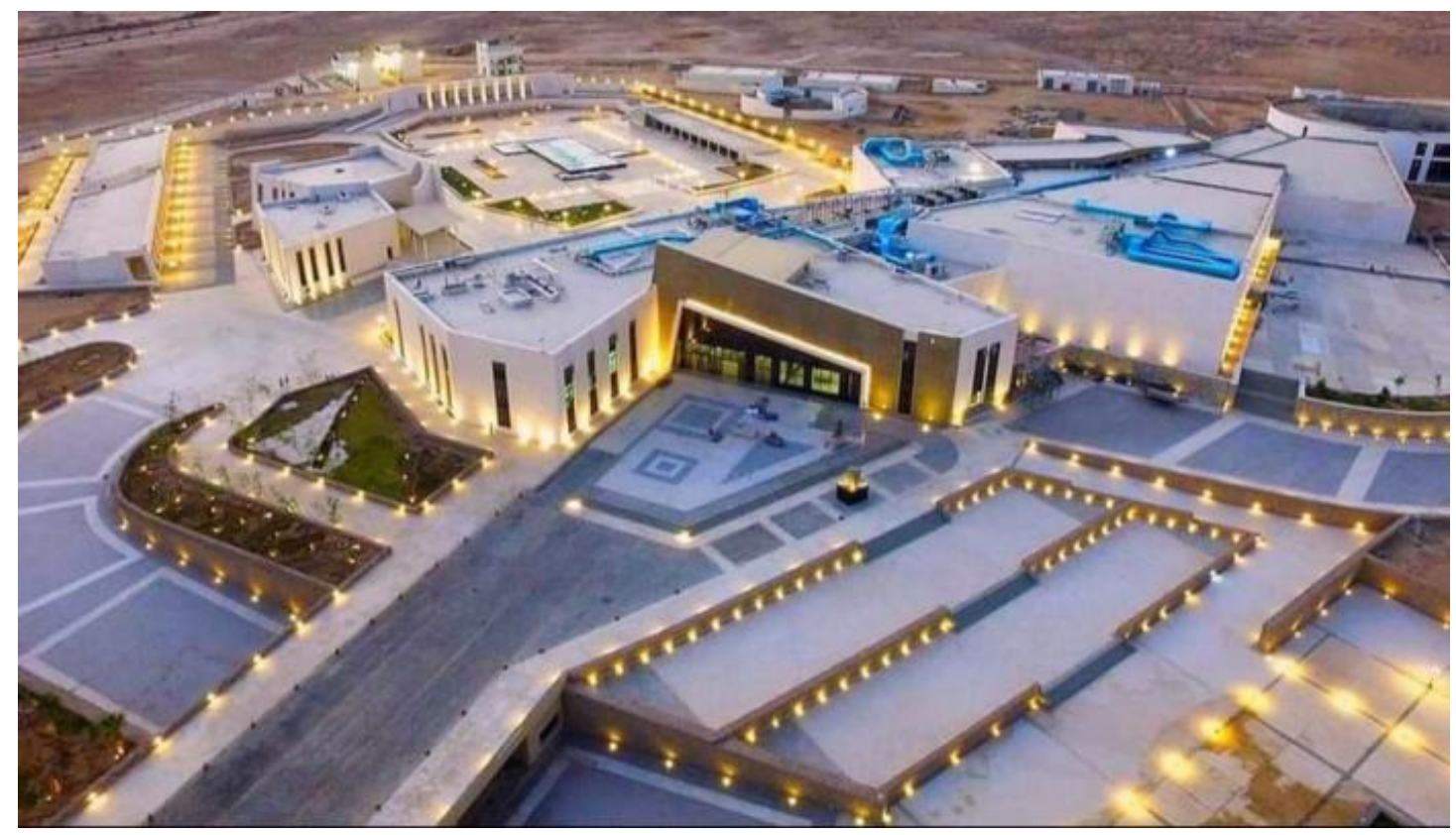

Fig (7) Hurghada Antiquities Museum

\section{Private Museums in Egypt:}

Private museums are museums owned by non-governmental organizations (NGOs) or individuals. They contain a variety of folklore items, and in their efforts to preserve and care for the national heritage, the National Authority supports private museums on specific terms Related to the quality of performance. The private museums could, however, charge considerably lower admission fees to citizens and residents than to foreign tourists, as is the case currently at public museums.

\section{Oasis Heritage Museum :}

Represents a vivid memory of the people of the oases, created by an automatic artist to preserve the customs and traditions of the oasis, it took a year and a half to prepare and equip the museum, where the first nucleus began in 1995, the museum presents statues of some famous figures of the oasis, the way of life in the desert and the design of houses in the sea oases including customs, traditions and innovative tools for use in daily life in addition to models of famous oases industries such as olive oil industry. 


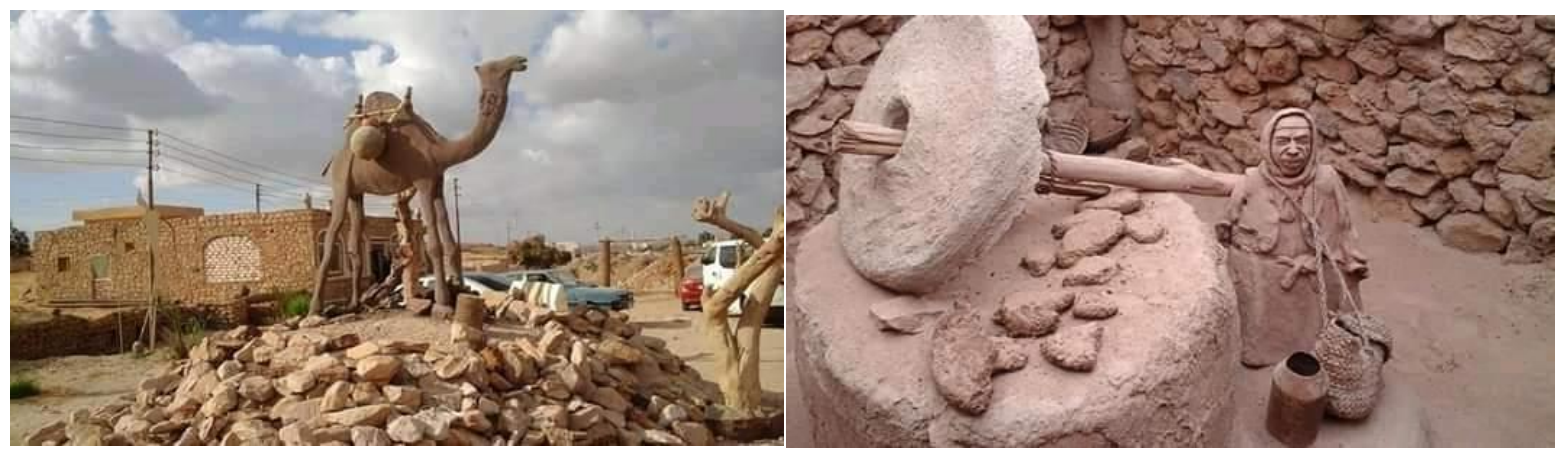

Fig (3) Bahria Oasis Museum.

\section{Halaib and Shalitin Heritage Museum}

The Museum, which collects all the collections of the Bejawi community, preserves the culture of the inhabitants of the Halaib Triangle among its walls by displaying all the leather artifacts and handicrafts of the java, an individual effort of the owner of the museum.

The museum reflects a special Egyptian heritage carried by the tribes of halaib and Shalitin region over successive generations, to be unique, and the private museum founded nearly 11 years ago, contains a variety of pots and pottery, wood and stone, as well as pots made of palm fronds, as well as a rare collection of ancient swords and daggers, as well as shields made of leather, as well as a large number of historical coins. It also includes a distinct collection of women's collections, such as bracelets, earrings, silverware, ornaments, and gemstones that were used for decoration, as well as some wooden ankles and purses, perfume-keeping bottles, and khoal (hair comb), which were used by women in ancient times, some of which are still in use today.

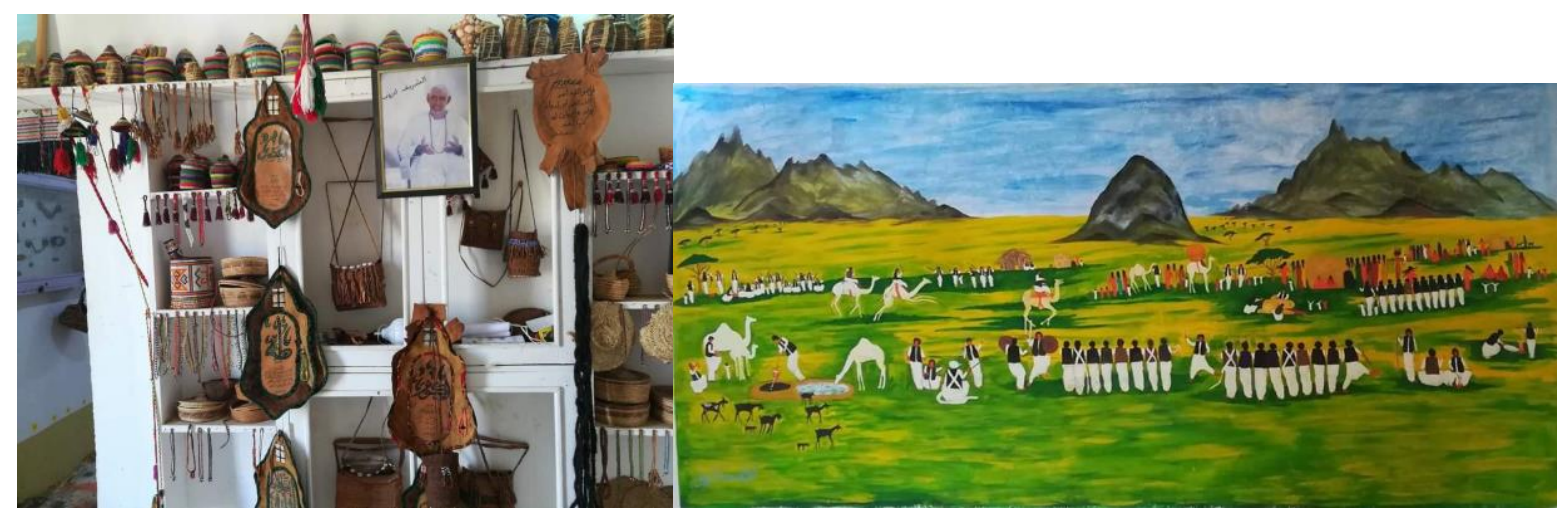

Fig (4) Halaib and Shalitin Heritage Museum.

\section{Al Qasr Heritage Ethnographic Museum, Dakhla Oasis:}

A little museum located in the entrance of Medaint Al Qasr, Dakhla Oasis, established by Dr. Aleya Hassan professor of sociology Cairo University, This little museum occupied a house 
dating back to 1785 and had two levels of rooms displaying: Berber and Bedouin clothes, jewelry, pottery, and other artifacts. A few rooms were divided into typical living areas, kitchen, etc. (Fig 5).
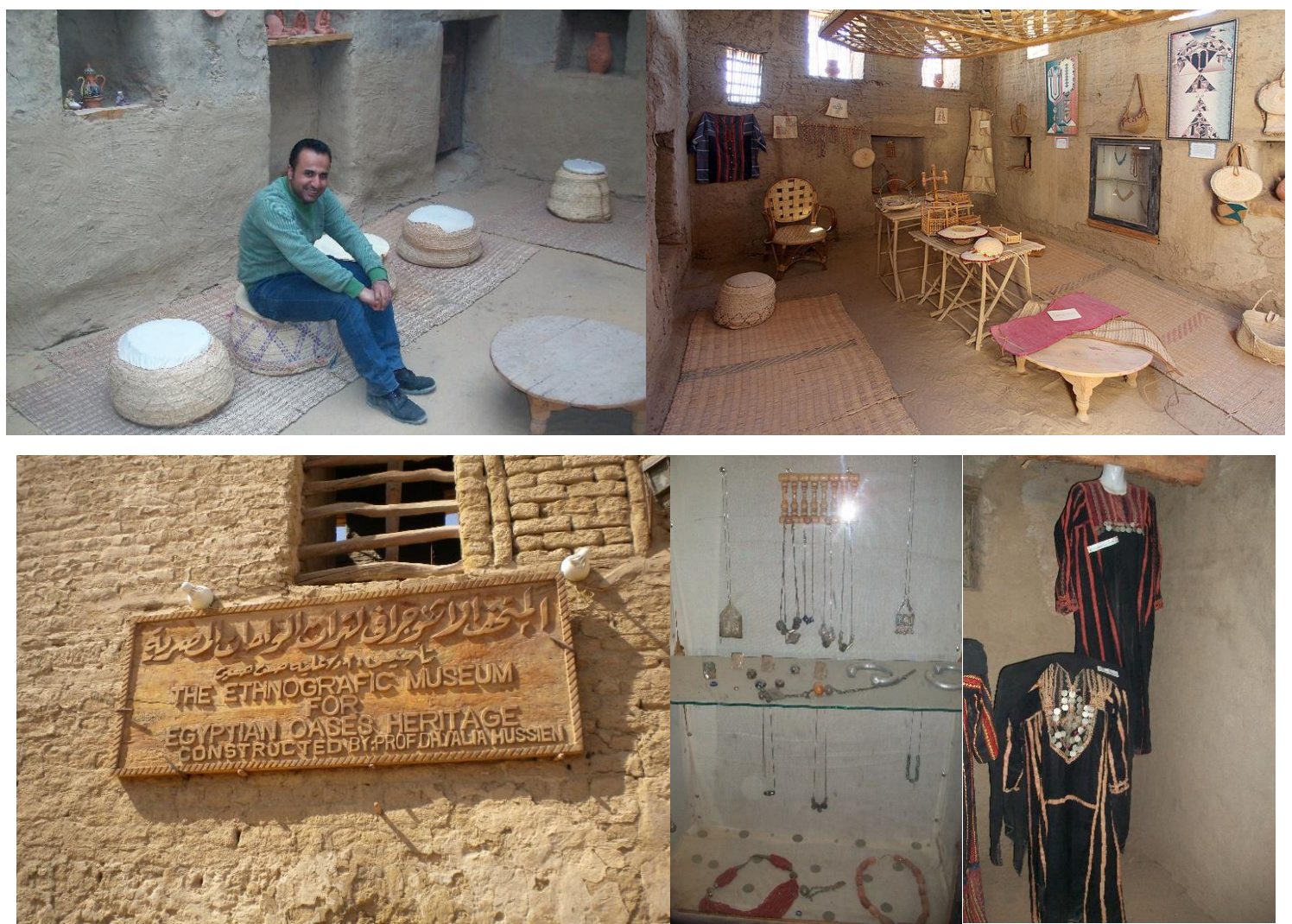

Fig (5) Ethnographic museum for Egyptian Oases Heritage- source: Shaikhon

\section{El-Farafra Museum:}

The museum is situated in the Western Desert region and not far from the White Desert making it very accessible for tours. On approach to the Museum which is about 3 kilometers east of the town of Farafra ,Badr's Heritage Museum located in Farafra Oasis, established by Mr. Badr Abdel-Moghni is a native of the Oasis, a self-taught artist who encapsulates the local life in sculpture, oil, and watercolors. He has shaped models out of local clay into postures illustrating the crafts and pastimes of the people of Farafra and exhibits them in a custom-built museum, together with a collection of local objects. He is also a mine of information about the life and culture of the oasis. Some of Badr's most striking work is in local sandstone which he carves into distinctive figures and features. The museum in Farafra gives a truly wonderful and informative look at this period (fig4). 


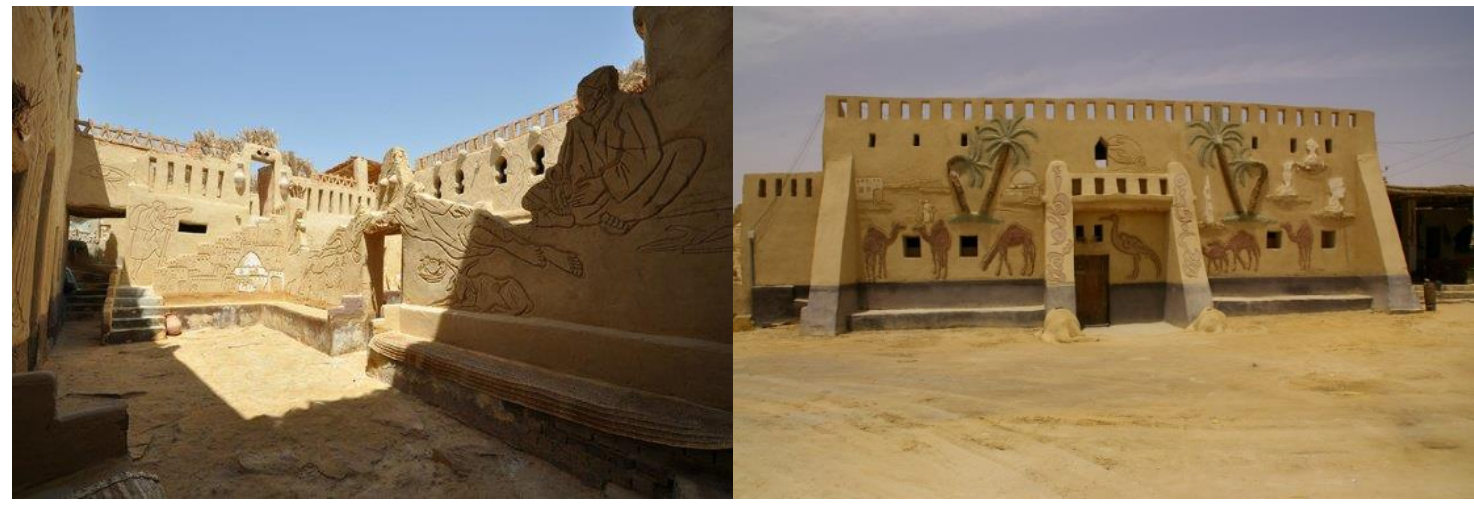

Fig (6) Badr Museum in Farafra Oases source: http://www.egypt.travel/attractions/badr-museum

\section{Conclusion:}

The opponents' point of view could be summarized as: "The government should not abandon cultural support under the pretext of financial restructuring"; and, "Once 'privatized' and ruled by capital, museums might become unable to sustain activities that won't yield profit, such as research and conservation of cultural assets. Instead, they might be focusing on crowd-pulling exhibitions only." Those who favor "privatization" cite among the merit freedom in budgetary affairs and other policies (multiple-year budgets, unrestrained fund-raising, etc.) as well as possible improvement in service. All of them are rightfully claiming that the government should clarify in which way an "independent administrative corporation" should be structured, so they can scrutinize the pros and cons of "privatization" more carefully.

\section{References:}

- Anderson, G. M. (1991) "The Fiscal Significance of user charges and earmarked taxes: A Survey", in Wagner, R. E. (Ed.) Charging for Government: User Charges and Earmarked Taxes in Principle and Practice. London: Routledge, pp. 13-33.

- Hooper-Greenhill, E. (1992) Museums and the Shaping of Knowledge. London: Routledge.

- ICOM, Museums of Archaeological Sites, Report prepared by Council International Museums, UNESCO, Paris.

- Mclean, F. (1997) Marketing the Museum. London: Routledge.

- Moore, K. (Ed.) (1994) Museum Management. London: Routledge.

- Samuel, R. (1999) Theatres of Memory, London: Verso

- Schubert, K. (2000) The Curator's Egg: The Evolution of the Museum Concept from the French Revolution to the Present Day. London: One-Off Press.

- Steven Englesman (1996): privatization of museums in the Netherlands twelve years later, museum international no.48, vol. 4, 1996. 
- Urice, S. (1995) "Privatising the Public Museum". Background material prepared for the ALI-ABA Course of Study, Legal Problems of Museum Administration 26-28 March. San Francisco, CA.

- Veniris (2013) "Crisis Social Policy and Social Justice: The Case for Greece” Greece Paper No. 69 Hellenic Observatory Papers on Greece and Southeast Europe.

- West, B. (1988) 'The Making of the English Working Past: a critical view of the Ironbridge Gorge Museum' in R. Lumley (ed) The Museum Time-machine: Putting cultures on display, 35-62, London; New York: Routledge.

- Yupin Chung (2003): Pricing Policy for Museums: Should We Privatize Public Museums? A Case Study from Taiwan.

- Ahmed Motawea Hussein SHAIKHON, MANAGING UNDERWATER HERITAGE IN EGYPT, International Journal of Advanced Studies in World Archaeology, Vol. 2, No. 1, 2019, pp. 1-13

- Ahmed Motawea Hussein SHAIKHON, HIDDEN HERITAGE OF ALEXANDRIA, EGYPT, International Journal of Advanced Studies in World Archaeology, Vol. 2, No. 2 , 2019, pp. 1-13.

Received: February 13, 2020

Accepted: April 10, 2020 